\title{
Effects of heat-treated Moringa oleifera leaf-meal on the growth performance of Oreochromis niloticus
} fry.

${ }^{1}$ Department of Environmental Science, Bindura University of Science Education, P. Bag 1020, Bindura, Zimbabwe.

${ }^{2}$ Faculty of Agriculture, Umutara University, P. O. Box 57, Nyagatare, Rwanda.

${ }^{3}$ Tree Africa, P. O. Box AV 25, Avondale, Harare, Zimbabwe

${ }^{4}$ Lake Harvest International, P. O. Box 40, Kariba, Zimbabwe.

*Corresponding author: timupangwa@yahoo.com

\begin{abstract}
The high cost as well as the uncertain availability of fish-meal have led to the need to identify alternative plant protein sources for feeding Oreochromis niloticus. Moringa oleifera is a promising protein source for inclusion in fish diets. The study was conducted to determine the suitability of heat-treated $M$. oleifera leaves as an alternative protein source for Oreochromis niloticus fry. Four experimental diets were formulated to contain heat-treated moringa leaf-meal at levelsfo $\%$ and $10 \%$ of the total dietary protein. Diet A contained $5 \%$ boiled moringa and $95 \%$ fry-meal; Diet B contained $10 \%$ boiled moringa and $90 \%$ fry meal; Diet C contained $5 \%$ steamed moringa and $95 \%$ fry-meal and Diet D contained $10 \%$ steamed moringa and $90 \%$ fry-meal. Diet $\mathrm{E}$ was the control diet containing fish-meal as the protein source. A standard 24-day fry feeding trial was carried out in 10 fry tanks that were randomly allocated to the five dietary treatments. Each tank was stocked with 15000 fry, the standard stocking rate at Lake Harvest. No feed-related mortality was observed during the whole experimental period. The growth rate, feed conversion ratio(FCR) and protein efficiency ratio of fry fed the five diets were similar. The daily body weight gain ranged from 0.012 to 0.014 grams for fry fed boiled moringa and the control diets. Fry fed diets $\mathrm{C}, \mathrm{D}$ and $\mathrm{E}$ had higher FCR values of 1.1, 1.1 and 1.0, respectively, compared to those on diets A and B, which had values of 1.2 and 1.3, respectively. In general, fry fed steamed moringa diets had better growth performance than those on boiled moringa diets although the differences were not significant. The results suggest that steam-heated moringa leaf-meal can be used to substitute $10 \%$ of dietary protein in Nile tilapia fry without significant reduction in growth performance.
\end{abstract}

Keywords: Moringa oleifera, heat treatment, fish-meal replacement, growth performance.

\section{Introduction}

The Nile tilapia (Oreochromis niloticus) was one of the first fish species cultured and is still the most widely cultured species of tilapia in Africa. Positive aquacultural characteristics of tilapia species include their tolerance to poor water quality and the fact that they eat a wide range of natural food. Of the total world production of fish, which amounted to 112.30 million tonnes in 1995, $18.97 \%$ came from the aquaculture sector while the rest came from captured fishery (FAO, 1998). Most of the increase in fish production is expected to come from aquaculture, which is currently the fastest "growing food production sector of the world (FAO, 2000).

In aquaculture systems the increasing price of feed is considered one of the most important 
factors that limit profitability, caused mainly by the cost of fish-meal used as a primary source of protein (Usmani et al., 1997; McCoy, 1998). As a result, there is a need to search for alternative protein sources for aquaculture diets. Olvera et al. (1990) noted that the high cost and fluctuating quality of imported fishmeal have led to the need to identify alternative protein sources for use in fish feed formulations. The identification and utilization of non-conventional and lesser-utilized plant protein sources to replace fishmeal, either partially or totally in practical fry diets has been an area of focus in aquaculture nutrition (Hossain et al., 2003). Earlier studies have shown that Moringa oleifera is a promising protein source for inclusion in fish diets at low levels (Becker et al., 2002, Chiseva, 2006). Plant proteins are cheap and readily available, but have some anti-nutritional factors that limit their use as aquaculture feeds. These limitations could be successfully overcome by different methods of heat treatment (Olvera et al., 1990; Afuang et al., 2003). The objective of the study was to determine the effects of heat-treated moringa supplemented diets on the growth performance of the Nile tilapia (Oreochromis niloticus) fry.

\section{Materials and Methods}

\section{Experimental Animals}

$O$. niloticus fry with average body weight (ABW) of $0.01 \mathrm{~g}$ were taken from Lake Harvest hatchery and used in this study. The collection and transportation of the fry was done as recommended by Mgaya and Tamatamah (1996) and Collart (1997). They were taken to the experimental tanks in the early hours of the day from 0500 to 0700 hours.

\section{Fry tanks and fry stocking}

The experimental tanks were thoroughly cleaned with fresh water before the experimental fry were introduced. A total of ten fry tanks were used and each treatment diet was randomly allocated to two fry tanks.
Water in the fry tanks was continuously changed throughout the experiment that lasted for 24 days. A compressor was used to supply oxygen into fry tanks via air stones and this ensured adequately dissolved oxygen to be above $80 \%$ saturation. Each experimental tank with a volume of $3.16 \mathrm{~m}^{3}$ was stocked with 15000 fry.

\section{Fry Management}

The fish fry were acclimatized in the experimental tanks for 3 days while feeding on a standard diet of 40 $\%$ crude protein. The fry were starved for a day before experimental feeding started. The fry were weighed at the beginning and progressively at weekly intervals. No feed was given on the weighing days in order to prevent stress.

\section{Processing of moringa leaves and diet preparation}

M. olifera leaves were taken from Lake Harvest forestry unit and were dried under shed. After drying, some of the leaves were heat treated either by boiling or steam heating at a temperature of between $60^{\circ} \mathrm{C}-$ $80^{\circ} \mathrm{C}$ for 15 minutes. Steam heating and boiling were meant to minimize or deactivate the anti-nutritive factors such as tannins, phytic acid and saponins that inhibit the digestion of plant proteins in Nile Tilapia. After the heat treatments the leaves were allowed to dry under shed before being milled through a 0.01 $\mathrm{mm}$ screen. The moringa leaf meal was then incorporated into the fry feed after milling .

Four diets were formulated to have $450 \mathrm{~g} / \mathrm{kg}$ dry matter (DM) of crude protein (CP). Diets A and C were composed $65 \%$ boiled $\mathrm{dr} 5 \%$ steamed moringa leaves respectively, whilst $95 \%$ by mass was fry meal. Diets B and D were composed of 10 $\%$ boiled and $10 \%$ steamed moringa leaf meals respectively, whilst $90 \%$ by mass was the fry meal. The standard fry-meal, diet E, which contained no moringa leaf meal, served as a control and had fishmeal as a protein source. 
Table 1 indicates both dietary and chemical nutrient composition of the treatments under the study.

\section{Feeding}

The fry were fed a daily ration at a rate of $15 \%$ of body weight. The daily ration was divided into eight feeds given at hourly intervals from 0800 hours to 1500 hours. The quantity of food was adjusted weekly after weighing of fry. Mortality was recorded daily and so the quantity of feed was adjusted according to the total fry weight in the tank.

\section{Data collection}

The fry in each tank were weighed weekly in order to assess their growth performance. A Tefal electronic digital scale was used to measure weights of fry per week. The fish fry were weighed and returned into their respective fry tanks. No feed was offered during sampling days. Salt was added to fry tanks at a rate of $5 \mathrm{mg} / \mathrm{l}$ after sampling to prevent stress which would have caused high mortalities.

Growth performance was analyzed in terms of total body weight gain (BWG), average daily gain (ADG), feed offered (FO), feed conversion ratio (FCR), protein efficiency ratio (PER) and survival percentages. The following formulae as described by Siddhuraju and Becker (2003) were used:

BWG $(\mathrm{g})=$ Final body weight - Initial body weight

$\operatorname{ADG}(\mathrm{g} / \mathrm{d})=\mathrm{BWG} / 21$ days

$\mathrm{FO}=$ Total dry feed offered $(\mathrm{g})$

FCR $=$ Total dry feed offered (g)/ Live body weight gain $(\mathrm{g})$

PER $(\%)=$ Wet body weight gain $(\mathrm{g}) /$ Crude protein fed $(\mathrm{g})$

\section{Laboratory analysis}

The diets were analyzed for dry matter (DM), crude protein (CP), crude fibre (CF), Ash, Ca, $\mathrm{P}$ and energy content using the standard procedures of the AOAC (1990).

\section{Statistical analysis}

The growth performance was analysed using the oneway analysis of variance (ANOVA) using Minitab Version 12.1.

\section{Results}

\section{Chemical composition of diets}

The chemical composition of the diets is presented in Table 1. The diets had CP content that ranged from 45.4 to $46.9 \%$. The crude fibre of the diets that contained moringa leaves was high, ranging from 2.95 to $4.17 \%$ as compared to that of fry-meal of 1.97 $\%$. The ash content of diet A and C was higher as compared with other diets as shown in Table 1 . The calcium and phosphorus concentration in the diets was not different. The energy content of the five diets ranged from 8.2 to $12.5 \mathrm{MJ} / \mathrm{kg}$.

\section{Feed intake, growth performance and feed utilization}

The growth performance and feed utilization in terms of body weight gain (BWG), average daily gain (ADG), feed conversion ratio (FCR) and protein efficiency ratio (PER) are presented in Table 2. There was no rejection of feed until the end of the experiment and the acceptability of the diets was similar. No mortality or any signs of disease were observed in any of the dietary groups during the study period. 
Table 1: Proximate composition of experimental diets (\% on DM basis)

\begin{tabular}{llllll} 
COMPONENTS & DIET A & DIET B & DIET C & DIET D & DIETE \\
\hline & & & & & \\
Dry matter & 87.9 & 89.9 & 88.1 & 89.6 & 90.00 \\
Crude protein & 46.5 & 45.4 & 46.7 & 46.4 & 46.9 \\
Crude fibre & 3.44 & 4.17 & 2.95 & 3.32 & 1.97 \\
Ash content & 17.27 & 13.37 & 18.57 & 11.03 & 11.12 \\
Calcium & 2.42 & 2.68 & 2.48 & 2.49 & 2.41 \\
Phosphorus & 1.42 & 1.5 & 1.76 & 1.14 & 1.07 \\
M.E(MJ/Kg) & 10.7 & 9.8 & 8.2 & 12.3 & 12.5
\end{tabular}

\section{KEY:}

${ }^{1}$ Diet A contains $5 \%$ boiled moringa leaves and $95 \%$ fry-meal

Diet B contains 10\% boiled moringa leaves and $90 \%$ fry-meal

Diet C contains $5 \%$ steamed moringa leaves and $95 \%$ fry-meal

Diet $\mathrm{D}$ contains $10 \%$ steamed moringa leaves and $90 \%$ fry-meal

Diet $E$ contains fry-meal only

There was no significant difference $(\mathrm{P}>0.05)$ on total body weight gain and average daily gain of the fry fed the five diets. Fry on diets C, D and E produced the best FCR and PER as compared to all other diets, but this did not differ significantly $(\mathrm{P}>0.05)$. In general, among the five diets, fry fed diets containing steamed moringa leaves showed better growth performance in terms of final body weight, gain in body weight, FCR and PER than those fed boiled moringa leaves.

The growth curves of fish fed the five experimental diets are shown in Fig 1. The growth of the fry showed a similar trend on all the diets during the 21-day fry stage. There was an increase in average body weight among the fry with those fed the control diet having a higher weight followed by fry fed steamed moringa leaves and lastly those fed boiled moringa leaves. Fry fed a diet with $10 \%$ steamed moringa leaves tended to have a higher average body weight than those fed with $5 \%$ steamed moringa leaves. On the other hand, fry fed a diet with $5 \%$ boiled moringa leaves had a better average body weight than those on 10 $\%$ boiled moringa leaves.

Table 2: Growth performance and nutrient utilization of tilapia fed different experimental diets

\begin{tabular}{llllll} 
COMPONENTS & DIETA & DIET B & DIET C & DIET D & DIETE \\
\hline IBW $(\mathrm{g})$ & 0.01 & 0.01 & 0.01 & 0.01 & 0.01 \\
FBW $(\mathrm{g})$ & 0.261 & 0.253 & 0.279 & 0.288 & 0.298 \\
BWG $(\mathrm{g})$ & 0.251 & 0.243 & 0.269 & 0.278 & 0.288 \\
ADG $(\mathrm{g} / \mathrm{d})$ & 0.012 & 0.012 & 0.013 & 0.013 & 0.014 \\
FO $(\mathrm{g})$ & 3074 & 3074 & 3074 & 3074 & 3074 \\
FCR & 1.2 & 1.3 & 1.1 & 1.1 & 1.0 \\
PER & 1.8 & 1.7 & 1.9 & 2.0 & 2.0 \\
\hline
\end{tabular}


$\mathrm{IBW}=$ initial body weight, $\mathrm{FBW}=$ final body weight, $\mathrm{BWG}=$ body weight gain, $\mathrm{ADG}=$ Average daily gain, $\mathrm{FO}=$ Feed offered, $\mathrm{FCR}=$ Feed conversion ratio, $\mathrm{PER}=$ Protein efficiency ratio

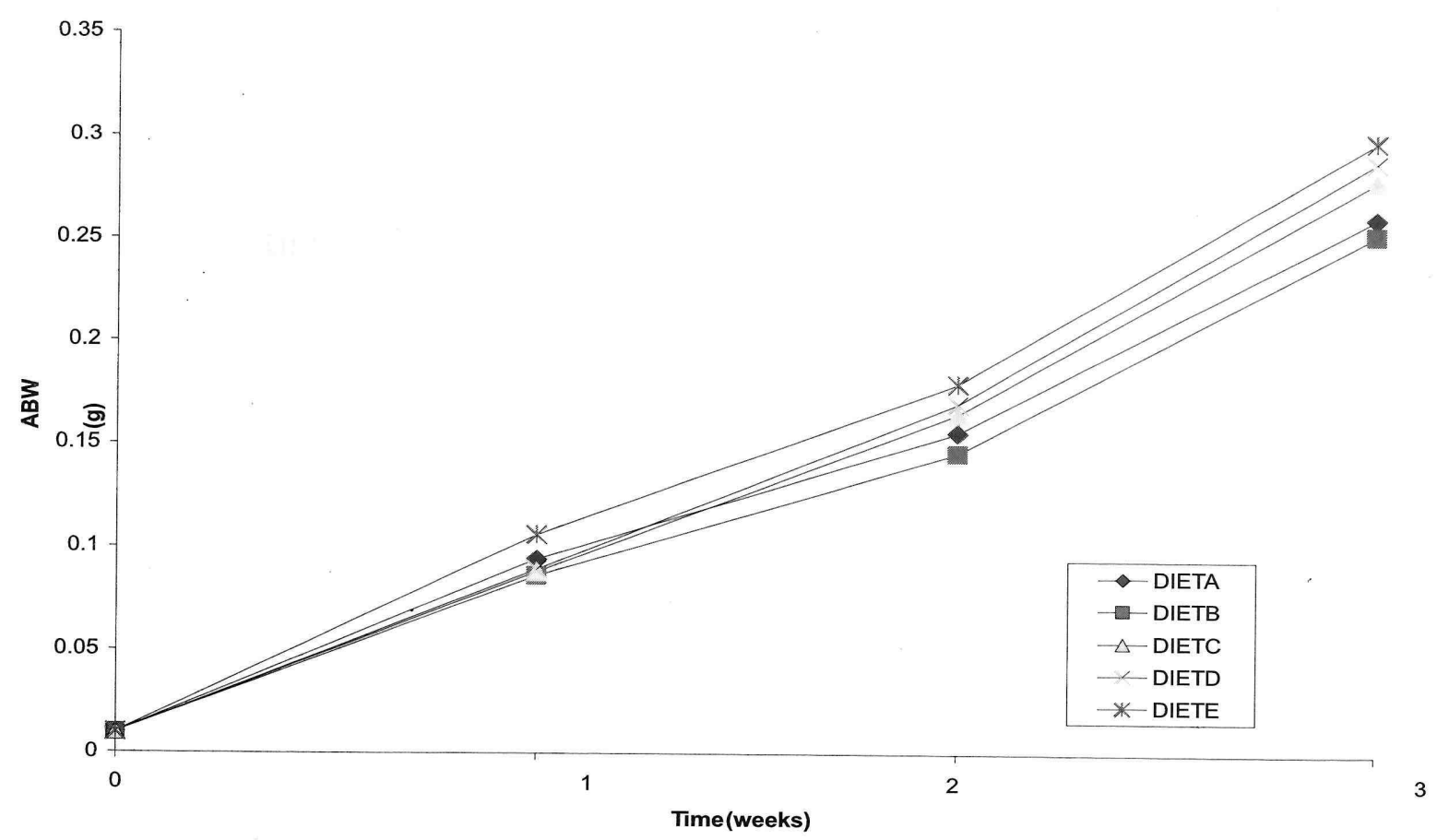

Figure 1:Growth curves of fish fed the five experimental diets.

\section{Discussion}

The crude protein content of the experimental diets used in this study was within the range used in a previous study by Usmani et al., (1997). Protein is very important in fish growth and thus a crucial ingredient in fish diets. A comparison between the amino acid composition of the raw and extracted moringa leaves to that of soybean revealed an almost identical composition of essential amino acids (Makkar and Becker, 1996). The proximate analysis of the experimental diets showed that the crude protein was ranging from $45.4 \%$ to $46.9 \%$. This range is within Lake Harvest requirements for the growth of fry which ranges from $45 \%$ to $47 \% \mathrm{CP}$.
The diet which contained $10 \%$ steamed moringa leaves (Diet D) showed the highest growth performance as compared to all other formulated diets, except for the fry-meal (Control diet) although the differences were not statistically different. In terms of growth rate, fish which received the diet containg $5 \%$ steamed moringa (Diet C) had low growth rate as compared to diet D. This is contrary to the previous study carried out by Richter et al. (2003) which showed that higher inclusion levels of moringa leaves in fish-meal had an impact on lowering the growth performance because of the presence of anti-nutrients such as phenols, tannins, phytates and saponins. This present study indicate that a $10 \%$ inclusion level of moringa in fry-meal yielded good growth performance possibly because the 
antinutritrients such as phenols, tannins, phytates and saponins could have been inactivated by steam heating as suggested by Rweyemamu (2005). This could have resulted in the reduction of palatabilityreducing factors.

Heat treatment methods employed might have increased the digestibility of proteins and other dietary components such as starch related compounds leading to high FCR and PER in fish fed with diets C and $\mathrm{D}$. The reduction in antinutrients by processing techniques such as soaking, drying and heat treatment on plant-based fish ingredients have resulted in better palatability, increased feed digestibility and growth in fish.

Generally steam heating reduces loss of soluble nutrients from moringa leaves since that process does not involve a solvent media to dissolve the nutrients. Apart from that, steaming employed in this study might have resulted in little protein being denaturated thus making more quality protein available in steamed leaves than boiled leaves.

Boiling breaks cell components like cell walls and cell membranes of plants cells. Some of the nutrients within the cells of boiled moringa leaves were lost to boiling water during the heat treatment process. The soluble cell components such as soluble proteins and glucose molecules might have dissolved in water during boiling. This could have caused the reduction of essential amino acids (EAA) in $\operatorname{diet} \mathrm{A}$ and $\operatorname{diet} \mathrm{B}$. Boiling might have caused the inactivation of anti-nutrients such as saponins, phytates, phenols and tannins that bind some quality proteins and inhibit digestion in fish. Apart from breaking the cell components; boiling induces the precipitation of polyphenolic and other phytochemical compounds which might have depressed the growth of fish receiving feed with boiled moringa leaves (Rweyemamu, 2005). Boiling also induces the formation of colloidal starches and as a result this reduces the amount of available glycoproteins to fish (Rweyemamu, 2005).

Boiling and steaming showed no significant effect on the crude fibre content but it was within Lake Harvest requirements for the growth of fish; except for diet $B$ that had a higher crude fibre content of $4.17 \%$. This might have contributed to the growth rate of fish fed with diet $\mathrm{B}$ being the lowest. It has been shown that fibre can bind nutrients like fats, proteins and essential minerals, and reduce their bio-availability (Richter et al., 2003). Dietary fibre apparently influence the movement of nutrients along the gastrointestinal tract and significantly affect nutrient absorption.

\section{Conclusion}

The results of this study indicate that up to $10 \%$ inclusion of steam heated moringa leaves can be recommended for Nile tilapia. In view of the favorable amino acid profile of moringa leaves and their wide and ready availability throughout the tropics and subtropics, moringa can be considered as a potential feed component with high nutritive value for Nile tilapia. 


\section{References}

Afuang W., Siddhuraji P., and Becker K. 2003. Comparative nutritional evaluation of raw, methanol extracted residue and methanol extracts of Moringa (Moringa oleifera Lam.) leaves on growth performance and feed utilization in Nile tilapia (Oreochromis niloticus L.). Aquaculture 34: 1147-1159

AOAC, 1990. Official Methods of Analysis, $15^{\text {th }}$ Ed. Association of Official Analytical Chemists, Arlington, VA.

Becker, K., Ritcher, N., and Siddhurajur, P. 2002. Nutritional quality evaluation of Moringa (Moringa oleifera Lam.) leaves as an alternative protein source for Tilapia (Oreochromis niloticus L.) Germany.

Chiseva, S. 2006. The growth rates and feed conversion ratios of fry fed conventional fry diets and Moringa oleifera supplemented diets. B. Sc. Dissertation, Bindura University of Science Education.

Collart A. 1997. Monosex rearing of Nile tilapia (Oreochromis niloticus). Handbook of family and small-scale mono-sex Nile tilapia farming in tropical Africa. Tilapia International Association. Belgium.

FAO, 1998. Code of Conduct for Responsible

Fisheries. Food and Agricultural

Organization of the United Nations, Rome.

FAO, 2000. Yearbook of Fishery statistics 1998.

Vol. 86/2. Aquaculture production. FAO statistics series No.154 and Fisheries series No.56, FAO, Rome.

Hossain M.A., Focken U. and Becker K. 2003. Antinutritive effects of galactomannan- rich endosperm of Sesbania (Sesbania aculeata) seeds on growth and feed utilisation in tilapia, Oreochromis niloticus. Aquaculture Research 34: 1171 - 1179.

McCoy, H. D. 1998. Fish-meal. The critical ingredient in aquaculture feeds. Aquaculture Magazine 16(2), 43-50.

Mgaya Y.D. and Tamatamah R. 1996. The farming of marine organisms: Unpublished training manual developed for Tanga coastal zone conservation and development programme.

Olvera, N.M.A., Campus, G.S., Sabido, G.M., Martinez, P.C.A. 1990.The use of alfalfa leaf protein concentrates as a protein source in diets for tilapia (Oreochromis mossambicus). Aquaculture 90: 291-302.

Richter N., Siddhuraju P. and Becker K. 2003. Evaluation of nutritional quality of Moringa (Moringa oleifera Lam.) leaves as alternative protein source for tilapia (Oreochromis niloticus L.). Aquaculture 217: 599-611.

Rweyemamu L.M.P. 2005. Influence of additives on quality characteristics of Moringa leaf paste. IEF Annual seminar proceedings. Tanzania.

Sidduraju, P. and Becker, K. 2003. Comparative nutritional evaluation of differentially processed mucuna seeds [Mucuna pruriens (L.) DC. var utilis (Wall ex Wight) Baker ex Burck] on growth performance, feed utilisation and body composition in Nile tilapia (Orechromis niloticus L.). Aquaculture Research 34: 487 - 500.

Usmani, N., Jafri, A.K., Alvi, A.S. 1997. Effects of feeding glanded cotton seed meal on the growth, conversion efficiency and carcass composition of Labeo rohita fry. Journal of Aquaculture in the Tropics 12:73-78. 